\title{
HUMAN DIGNITY - RESOURCES AND CHALLENGES FOR PUBLIC-THEOLOGICAL DISCOURSE AND PRACTICE IN AFRICA TODAY
}

\author{
GUEST EDITORIAL
}

Piet J Naudé

Unit for Ethics

Nelson Mandela Metropolitan University

$\mathrm{T}$

The Alexander von Humboldt Foundation (Germany) declared 2008 as a special year for research on the African continent. An invitation was sent to all past Humboldt scholars to submit proposals for a colloquium with a research theme relevant to the Africa continent. The guidelines were clear: Invite past Humboldt scholars who should make up approximately half of the participants. Draw together eminent scholars from related research fields in Germany, and provide opportunities to young scholars who show potential as leaders in the future academy.

A small group of Humboldt scholars reflected on this opportunity, and the following theme was agreed upon: Human dignity - Resources and Challenges for Public-theological Discourse and Practice in Africa Today.

The Humboldt Foundation agreed to fund the event which was held from 23-26 November 2008 at the Stellenbosch Institute for Advanced Studies (STIAS) in South Africa. The list of participants with their affiliations (as in 2008) was as follows:

- The German scholars were Prof B Oberdorfer (Systematic Theology: University of Augsburg) and Prof H Bedford-Strohm (Ethics: University of Bamberg).

- The Humboldt scholars from South Africa were Prof D Smit (Systematic Theology: Stellenbosch University); Prof E de Villiers (Ethics: University of Pretoria); Prof P Naudé (Christian Studies: Nelson Mandela Metropolitan University, Port Elizabeth); Prof L Jonker (Old Testament: Stellenbosch University); Prof I Swart (Social Studies: Unisa/ Stellenbosch University); Prof I Cornelius (Ancient Studies: Stellenbosch University); Dr C Burger (Communitas: DR Church, Stellenbosch).

- The young scholars were Ms A Taljaard (Doctoral student: Beyers Naudé Centre); Dr C le Bruyns (Lecturer: Stellenbosch University); Dr C Pauw (Researcher: Beyers Naudé Centre); Dr G Akper (Nigeria: Centre for Public Theology); Mr S Mahokoto (Doctoral student: Stellenbosch University); Rev V Vellem (SACC: Pretoria).

The papers were discussed in the colloquium and everyone was invited to make a submission for possible publication. When Scriptura was approached, the editorial team kindly agreed to make a special arrangement for a collection of papers from the colloquium, subject to normal refereeing procedures. Some colleagues had already committed their work to other publications, and the editor approached two further young scholars to make contributions, i.e. Dr Heike Springhart from Heidelberg, Germany (a visiting scholar at Nelson Mandela Metropolitan University shortly after the colloquium) and Dr Willem Fourie, a research associate at the Ethics Unit of the same university. The result is a collection of eleven multi-disciplinary essays on the theme of human dignity in Africa. Taken as a whole, a number of sub-themes emerge and the essays are grouped as follows: 
The first essay discusses the importance of the need for reflection on human dignity from a global, ecumenical perspective (Bedford-Strohm). This is followed by an exposition of the major historical forces that shaped the marginalization of Africa and that serve as a context for reflection on the theme of human dignity (Naudé; see also Koopman).

Five essays are devoted to social-ethical and systematic-theological reflections on the theme: The relation between "human dignity" and the "image of God" (Oberdorfer); Christological themes in the work of John Calvin (Koopman); the notion of human freedom as presented in the writings of Wolfgang Huber (Fourie); an elaboration on human dignity from the current debates on an "ethics of responsibility" (De Villiers); and the restoration of democracy and dignity through the process of re-education in Germany after the Second World War (Springhart).

Two essays focus on the Dutch Reformed family of churches: This first analyses how human dignity was conceptualised in the theological voices against apartheid in the latter part of the $20^{\text {th }}$ century (Pauw). The second argues from a WCC perspective on church unity, that the re-unification of the DRC family is directly related to the restoration of human dignity (Mahokoto).

There are two essays on "indigenous" African views: A contemporary essay analyses the terms serithi/isidima in relation to human dignity (Vellem). The collection closes with an interesting historical essay on how "the other" was perceived in ancient Egypt (3000-300 $\mathrm{BCE}$ ) and draws out the implications for human dignity and the question of xenophobia in Africa today (Cornelius).

The editor wishes to thank the following persons: Dirkie Smit for assistance with the Humboldt application; Willem Fourie who facilitated the referee reports and wrote most of the abstracts and keywords; David Morton who performed the major task of editorial assistant in proofreading all the essays; Jenny Junicke who provided administrative support and communication with the authors.

I express my sincere appreciation to the Alexander von Humboldt Stiftung who funded the project and the editors of Scriptura who herewith make our work available to a larger audience. The writers hope that this collection makes a valuable contribution to one of the most important debates in (South) Africa and globally today. 